Originally appeared in: Indo-Iranian Journal 36 (1993), 197-210.

\title{
Nasalization of the final ă in the Rgveda
}

\section{ALEXANDER LUBOTSKY}

$\S$ 1. The final $-\check{a}$ before a vowel occasionally appears as $-\check{a} \ddot{m}$ in the Rgveda. This occurs most frequently at the end of an odd numbered pāda (pādas a and c of anuṣtubh, triṣtubh, jagatī, pāda a in gāyatrī and all pādas without avasāna in complex metres), but sporadically the same phenomenon is found within a pāda. The material can be divided into three groups: we find nasalized -ă̆m before $\mathrm{e}$ - and o-, nasalized -ām̆ before ${ }_{0}$-, and -ām̆ in the postpositions á and sácā before any initial vowel. Here are some examples (the semi-colon indicates an odd pāda boundary, the comma indicates a caesura):

4.35.2cd sukrtyáyā yát, ș vapasyáyā cam̆ :

ékam vicakrá, camasám caturdhá //

1.60.4cd dámūnā, grhápatir dáma âm̆ :

agnír bhuvad, rayipátī rayīṇấm //

7.81.2ab úd usríyāh, srjate súríyạ̣ sácām̆ : udyád nákṣatram arcivát /

5.45.6b ápa yấ mātấm, rṇutá vrajám gón /

The creator of the Padapātha (Pp.) already recognized the secondary character of this nasalization and put unnasalized final $-\bar{a}$ in his text. Consequently, the Roveda-Prātisākhya (RPr.), which conscientiously notes down all discrepancies between the Samhitā text and that of the Pp., devotes several rules (164-170) to secondary nasalization. The more or less complete material can also be found in Bollensen 1868: 623 and Benfey 1880: 10ff. Attempts to find examples of secondary nasalization outside those listed by the RPr. were unsuccessful, ${ }^{1}$ so that the list of occurrences may be considered as definitive.

On the other hand, rules for the distribution of occurrences with and without nasalization have never been found. As Oldenberg admitted (Noten ad 1.33.4), "die Regeln über den Eintritt dieser Nasalisierungen sind so irrationell, daß sie ihrerseits Vertrauen zur Überlieferung nicht

\footnotetext{
${ }^{1}$ Lanman assumed secondary nasalization in 10.25.4 camasấm iva (1878: 335) and 6.67.1 jánām̆ ásamā (1878: 342), while Benfey (1880: 163ff.) proposed to consider nasalization secondary in 3.31.21 krṣ̣nấm aruṣaír and in 8.41.10 śvetấm ádhinirnijaś and krș̣nấm ánu. In all these passages the analysis of the pada-text is more probable, however (cf. Oldenberg, Noten ad loc.). Oldenberg (1901: 313, Noten ad loc.), in his turn, suggested nasalization in 6,15,9a vibhū́ṣann agna ubháyām̆ ánu vratấ, but here, too, the acc.pl. is more plausible, cf. the translations of Geldner and Renou: "Beide Teile nach den Geboten in Ordnung haltend..., Agni,...", "Consolidant, o Agni, l'une et l'autre (espèces: hommes et dieux) selon les décrets..." (EVP XIII: 47).
} 
erwecken können". All scholars considered nasalization as a device used by the editors to avoid hiatus and confined themselves to indicating a possible source from which the editors could get the idea to nasalize final vowels for that purpose. Bollensen (1868: 622) sought the source of 198 nasalization in rules of Prakrit versification. Benfey (1880: 10) compared the frequent nasalization of final vowels in Pāli and Prakrits, whereas, according to Oldenberg (1888: 469ff., Noten ad 1.33.4), nasalization in hiatus imitated secondary nominatives singular in -vā̄̆(s) before a vowel. Wackernagel (AiGr. I: 301ff., 314) merely refers to nasalized pronunciation of the final vowels, mentioned by Pāṇini $(8,4,57)$ and the Prātisākhyas (RPr. 64, TPr. 15,6) and attested in Middle Indic: "offenbar ist die Nasalirung, die in allen vokalisch auslautenden Zeilenschlüssen zulässig gewesen wäre, hier eher als sonst im Text festgehalten worden, um den Hiatus zu mildern" (p. 302).

All these proposals cannot be verified as long as we have not determined the distribution. We must therefore go back to the material because this is the only way to find out where the process started.

The material presented below has been taken from the lists of the RPr., Benfey and Bollensen and checked with the "electronic" pada-text of the Rogveda, which I am currently preparing on the basis of the machine-readable version of the Samhitā text, edited at the University of California (Berkeley) by G. Holland and B.A. van Nooten.

$\S 2$. Nasalization at the end of odd pādas

$\S$ 2.1. Nasalization of -ă before e-, o- (RPr. 166)

There are eighteen cases of nasalization:

\begin{tabular}{|c|c|}
\hline 1.33.4ab ghanénam̆ : ékah & 6.45.20ab pấrthivām̆ : ékạ̣ \\
\hline 1.35.6ab upásthām̆ : ékā & 6.46.5ab bharam̆ : ójiștham \\
\hline 1.110.5ab téjanenamँ : ékam & 7.25.4cd ugram̆ : ókaḥ \\
\hline 1.113.1cd savấyam̆ : evấ & 8.15.3ab puruștutam̆ : ékah \\
\hline 1.123.10ab sẫ̂́sadānām : éṣi & 8.15.11ab puruștutam̆ : ékah \\
\hline 2.14.2cd tadvasá̄áyam : eșá & 8.29.6ab yathām̆ : eșá \\
\hline cam̆ : ékam & 8.98.10ab bharam̆ : ójạ̣ \\
\hline 6.30.1ab vīryā̀yam̆ : ékaḥ & 8.100.5ab rtásyam̆ : ékam \\
\hline 6.34.2ab ŕ rbhvāmă : ékaḥ & 10.34.5cd akratan̆ : émi \\
\hline
\end{tabular}

While trying to find a common denominator for this list, we see that fifteen of the eighteen cases show the same accentual pattern, viz. unaccented -ă followed by accented é- or ó-. I think that this was not noticed before only because scholars like Bollensen and Oldenberg omitted the accent marks in their lists. In the following discussion I shall use the accentual terms of the RPr.: udātta for an accented vowel; svarita for a vowel immediately following an udātta; anudātta for a 
vowel immediately preceding an udātta; pracita for the other vowels. As is well known, a vowel between two udāttas is an anudātta.

We may now suggest that nasalization appeared only in the juncture anudātta - $\overline{\bar{a}}+$ udātta é/ó-. The three exceptions (once a pracita plus an anudātta and twice a svarita plus an anudātta) are then due to analogical extension of the original rule. In order to test this hypothesis let us examine the occurrences of $-\overline{\bar{a}}+$ e-/o- at a pāda boundary without nasalization. They are arranged in accordance with the accentual pattern:

udātta + udātta:

10.121.3ab mahitvá : ékaḥ (Samhitā mahitvaíkaḥ);

udātta + anudātta:

10.125.8cd prthivyá : etấvatī (Samihitā prthivyaítávatì);

pracita + anudātta:

7.33.3ab tatāra : evá (Samịitā tatārevá),

8.9.9cd ás vinā : evá (Samhitā aśvinevá),

$10.107 .8 \mathrm{~cd}$ svàs ca : etát (Samhitā svàs caitát).

As we can see, the pattern anudātta + udātta does not occur in the RV without nasalization, which confirms our hypothesis.

The RPr. accounts for non-nasalization in 7.33.3 and 8.9.9 by mentioning them in rule 176, which enumerates instances of the exceptional sandhi $-\breve{a}+e->-e-$ instead of -ai-. The other three cases are "explained" by an extra condition to rule 166, which says that nasalization of the final -ă before the pāda initial e-/o- only occurs luśād arvāg ‘before the Lúsa hymns'. As the first Lusa hymn is 10.35 , these passages are automatically excluded from the rule, whereas $10.34 .5 \mathrm{~cd}$ akratä̆ : émi falls just inside the given limits.

If the pāda-initial vowel is other than e- or o-, nasalization does not occur, e.g.:

6.41.1cd áchā : índra (Saṃitā áchéndra).

We may conclude that the original rule was $-\check{\bar{a}}>-\check{a} \bar{m} / \ldots$ : é-, ó-. The nasalized nom.du. 1.35.6a upásthām proves that this rule has been introduced by the editors. If poets themselves wanted to avoid hiatus, they would have used upásthāv : ékā (Oldenberg ad 1.33.4). The condition of an odd pāda boundary makes it evident that the nasalization was introduced at a stage when the metrical make-up of a pāda was still transparent to the editors.

$\S$ 2.2. Nasalization of -ā before ${ }_{\circ}-($ RPr. 168)

Long $\bar{a}$ at the end of a pāda appears three times with nasalization before ${ }_{o}$-:

2.28.4ab vidhartấm : rtám

4.1.12ab vipanyám : rrásya

5.30.14ab yấm : rṇamcayé 
In all the three cases we find the same accentual pattern: an udātta + a svarita or an anudātta, but there are two examples of the same accentual pattern, but without nasalization:

10.55.7cd mahná : roctekarmám (Saṃitā mahná róntekarmám), 10.114.6cd manịṣă : roskāmábhyām (Saṃitā manịsá rọksāmábhyām).

The latter exception may be explained by the unusual treatment of the word maniṣá in the Saṃitā text. The form manīṣá (nom.sg. and instr.sg.) occurs 27 times: $^{2} 7$ times at the end of pādas $b$ or $d, 14$ times at the end of pādas a or $c$, and only 6 times in the middle of a pāda. We find man̄ịấ 10 times before a vowel: ${ }^{3} 4$ times within a pāda and 6 times at a pāda boundary. The 4 times within a pāda are written with hiatus, which is irregular (cf. fn. 4), whereas at a pāda boundary 4 occurrences of manịsấ are written contracted with the following vowel and 2 (or 1, cf. fn. 3), at the end of a dvipadā virāj pāda, are written with hiatus. This distribution (contraction at the end of a pāda vs. hiatus within a pāda) may account for the treatment of maniṣáa in 10.114.6.

Incidentally, a comparable distribution is found with the so-called abhinihita sandhi (-e / -o $+a->-e / o \emptyset-)$. As is shown by the metre, in some passages this sandhi had already taken place in Vedic times, but in general the juncture -e/o a- remained unchanged. The text as we have it has preserved the original situation more or less faithfully (cf. Oldenberg 1888: 389ff.; the editors slightly extended the reach of the abhinihita sandhi), with one exception. When the juncture -e/o a- appears at the pāda boundary, the abhinihita sandhi is always found in the text, which must be due to a dogma of the editors.

The other accentual combinations of the juncture $-\bar{a}{ }_{o}^{r}$ - do not show nasalization and the final $-\bar{a}$ is shortened instead. Here is the complete material:

$$
\text { udātta + udātta: }
$$

1.151.4ab priyá : ŕctāvānau (Saṃhitā priyá rótāvānau);

anudātta + udātta:

8.3.14ab devátā : ŕọị (Sampitā deváta ŕșịh);

svarita + anudātta:

1.152.1cd vísvā : rrténa (Samhitā vísva réóna),

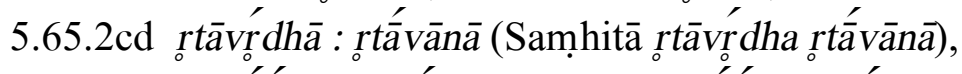

6.68.2cd tuvisúsmā : róóna (Samhitā tuvísúsma réna);

svarita + pracita:

\subsection{8ab ketúnā : rṣisvarám (Samhitā ketúna rọsisvarám);}

${ }^{2}$ Grassmann took by mistake 3.57.1 acc.sg. manīṣấm as a nom.sg. and omitted 7.71.6a, which is identical with 7.70.7a.

${ }^{3}$ There are doubts about the correct analysis of 1.70.1ab vanéma pūrvî́r aryó manịsấ agníh susóko vísvāny asyāḥ. The Pp. writes manịsắ and takes it as an instr.sg., whereas the Western scholars take it as the acc.pl. manīṣấh. 
pracita + anudātta:

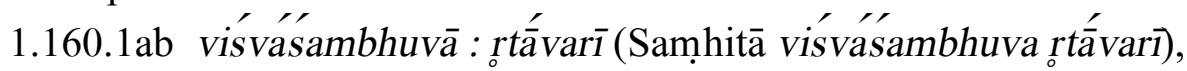

2.3.7ab vidúștarā : rojú (Saṃitā vidúștara rọjú),

5.7.3cd sávasā : rtásya (Samhitā sávasa rótasya),

10.36.2ab prácetasā : rtávarī (Samhitā prácetasa rốvarî̀),

10.66.13ab purohitā : rótasya (Samphitā purohita : rótasya),

10.102.6cd ánasā : rrchánti (Saṃitā ánasa róchánti);

pracita + pracita:

8.77.11cd súsamskrtā : rōūpé (Samhitā súsamskrta rōūpé).

$\S 2.3$. The postposition á $(\operatorname{RPr} .165)$

The postposition á always appears nasalized at the end of a pāda before a vowel, so that there is no phonetic distribution. For the sake of completeness I give the whole material (in Bollensen's list, 6.46.7 and 8.67.11 are missing; in Benfey's list, 8.18.11 is missing):

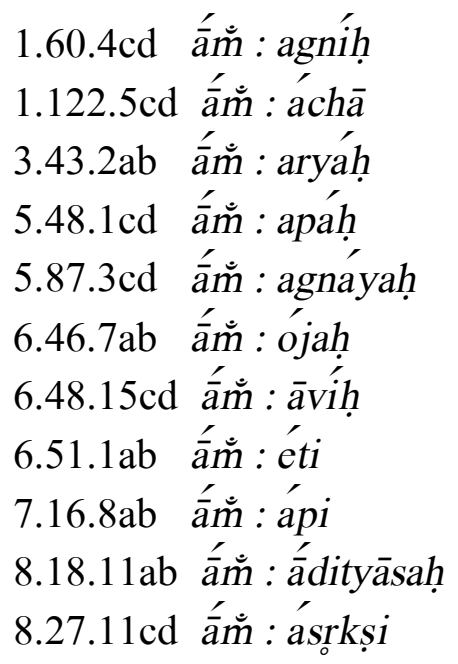

8.46.21ab ám̆ : ádevah

8.67.11ab ám : úgraputre

8.94.6ab ám̆ : índrạ̣

9.12.5ab ám : antár

9.68.6cd ám : uśrantam

9.86.23ab ám : índo

9.105.6ab ám : ádevam

9.110.4ab ám : rósya

10.91.12ab ám : ŕccah

10.105.4ab ám : upānasáh

The RPr. mentions one exception (rule 178):

10.105.1ab kadấ vaso stotrám háryata áva śmasáa rudhad vấh /

The metre of 10.105 is notoriously difficult (cf. Oldenberg 1888: 158f.). The RPr. assumes that pāda a ends with háryata $\bar{a}$, which is also the opinion of Arnold (1905: 323), who postulates for this hymn "the normal type ... 11.7.11" (p. 233) and takes pāda a as a Virātsthānā verse (of 10 syllables). Pādas of nine syllables are frequent in 10.105, however (e.g. 1c, 5a, 8a, 10c; cf. Oldenberg 1888: 159), and it seems more likely that the first stanza is of the type 9.7.9. Moreover, the function of á at the end of pāda a is unclear; it is more natural to take á and áva as preverbs of $\sqrt{ }$ rudh-. This would mean that $\bar{a}$ belongs to pāda $b$ and that there are no exceptions to nasalization of pāda-final á in hiatus. 
The reason for preserving hiatus after pāda-final $\bar{a}$ is obvious. Usually, á functions as a preverb, often standing at the beginning of a pāda, so that it was essential to show in the recitation where $\bar{a}$ is a postposition closing the pāda.

$\S 2.4$. The postposition sácā (RPr. 164)

The material is as follows:

1.51.11ab sácām : índrạ

1.139.7fg sácām : eșá

$1.161 .5 \mathrm{~cd}$ sácām : anyaíh

3.60.4ab sácām : átho 6.59.3ab sácām : ásvā

7.81.2ab sácām̆ : udyát

10.23.4ab sácām : índrạ

There are two exceptions to nasalization, mentioned by the RPr. in rules 177 and 176:

\subsection{4cd sácā : índra (Sampitā sácéndra) and}

5.16.5de sácā : utá (Saṃitā sácotá).

There can be no phonetic reason for different treatment of sácā in these two cases, as in 1.10.4 sácā stands before índra- just as in 1.51 .11 and 10.23.4, where its - $\bar{a}$ is nasalized. It is unclear, why the editors did not apply the nasalization rule here.

In contradistinction to the postposition $\bar{a}$, with sácā we find no consistent nasalization and no special reason for preserving hiatus. We may therefore conclude that the original nasalization rule for á was extended to sácā by the editors.

\section{§ 3. Nasalization within a pāda}

I shall present the material, which is much smaller than at a pāda boundary, in the same order as in the previous section, viz. nasalization in the position before e-, then before ${ }_{0}^{r}$, and finally the other cases. The postpositions á and sácā never show nasalization within a pāda.

\section{$\S$ 3.1. Nasalization before e-}

There is only one example of this treatment, mentioned by the RPr. in a separate rule 167:

\subsection{2a á te suparṇá, aminantam̆ évaiḥ :}

We find here the same conditions as at a pāda boundary: hiatus of an anudātta - $a$ and an udātta é-. But, in contradistinction to a pāda boundary, there are eight examples of a hiatus - $\breve{\bar{a}}+$ é- or $o$ - without nasalization. ${ }^{4}$ This state of affairs leads me to conclude that nasalization at a

\footnotetext{
${ }^{4}$ As was pointed out by Arnold (1905: 73f), hiatus after -ă is rare, contraction being eight times as frequent. It is therefore noteworthy that hiatus after unaccented -ă before accented é- or ó- is attested in seven different pādas $(1.30 .9 \mathrm{a}=8.69 .18 \mathrm{a}, 2.38 .5 \mathrm{a}, 4.19 .6 \mathrm{c}, 8.92 .6 \mathrm{~b}, 9.29 .1 \mathrm{~b}, 9.59 .2 \mathrm{~b}, 10.132 .4 \mathrm{~d})$, which is just as frequent as contraction (1.164.51b, 2.13.6d, 5.32.9d, 10.51.8c, 10.85.16c, 10.97.6a, 10.129.3d).
} 
pāda boundary was original and that its occurrence within a pāda is an editorial mistake.

Oldenberg (1888: 471, fn. 2) chose the opposite solution and considered the 1.79.2 case as original, which later spread to a pāda boundary. His argument was based on chronology: "Dass übrigens die Nasalirungen nirgends erscheinen, wo das Metrum die Contraction verlangt, spricht immerhin, wie ich glaube, dafür, dass diese Schreibung - wenigstens soweit sie das Innere des Pāda betrifft - nicht den jüngeren oder jüngsten Phasen der diaskeuastischen Textbehandlung, d.h. nicht derjenigen Periode angehört, in welcher man ohne jede Rücksicht auf das Metrum die einmal angenommenen Grundsätze in Bezug auf Contraction dem Text durchgehend aufzunöthigen gewohnt war" (p. 472). He repeated the same opinion in his Noten ad 1.33.4. I agree that nasalization originated at the first stages of editing, but this does not prove that nasalization at a pāda boundary is younger than within a pāda.

\section{$\S$ 3.2. Nasalization before $r$}

The RPr. (rule 168) mentions five occurrences of nasalization of -ā before ${ }_{\circ}$ - within a pāda. Two cases show nasalization in the same accentual context as at a pāda boundary, viz. accented -áa plus unaccented $r$-:

5.3.9d ágne kadấm, ractáid yātayāse //

5.45.6b ápa yấ mātấm, rṇutá vrajám gón /

The other three occurrences concern the nom.sg. víbhvām̆ before $r_{\circ}$-:

$4.33 .3 \mathrm{c}$ té vấjo víbhvām, rohúr índravantạ :

4.36.6d yám vấjo víbhvām, rọhávo yám áviṣuh //

7.48.3c índro víbhvāmă, rbhukṣá vájo aryáh :

Moreover, is it a mere coincidence that words in $-\bar{a}$, written in the Samhitā text with hiatus, almost always have final accentuation? From the RPr. (rules 162ff.) we can glean the following material: īșá (8.5.29b), manīsá $(1.101 .7 \mathrm{c}, 5.11 .5 \mathrm{a}, 7.34 .1 \mathrm{a}, 7.70 .7 \mathrm{a}=7.71 .6 \mathrm{a}$ vs. written contraction at the end of a pāda, cf. § 2.2), pūṣá (5.51.11c, $6.50 .5 \mathrm{~b}, 10.26 .1 \mathrm{~d}, 9 \mathrm{~b}$ vs. written contraction at the end of a pāda in 6.24 .5 , in places without hiatus, and only once, 4.57.7, where the metre demands hiatus) and root nouns in -áa (jyá, nidrá, prapá, śraddhá, svadháa ayá 1.87 .4 is a mistake of the Pp.). Add to this material 7.39.3 jmayá (Pp. jmayấh, cf. Wackernagel AiGr.I: 314 and Oldenberg, Noten ad loc.). The only cases of a written hiatus after unaccented $-\bar{a}$ are imperatives with lengthening of the final $-\bar{a}$ in 6.20.8d (mātụ̂ ná sìm úpa srjā iyádhyai), 8.17.1b ('́ndra sómam píbā imám) and, probably, 8.34.11b (ukthéṣu raṇayā ihá, cf. Oldenberg, Noten ad loc.).

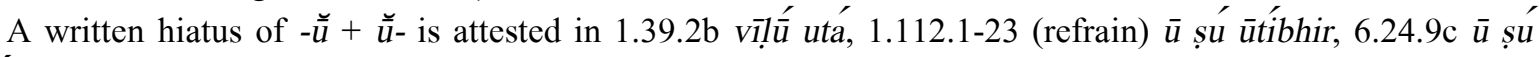
$\bar{u} r d h v a ́$, i.e. only when the first $-\breve{u}$ is accented (a written hiatus in another accentual context is found only in the compound suütayah in the refrain of 8.47).

Connection between accentuation and hiatus in the RV seems unmistakable and requires further investigation. 
This is the only case of nasalization of unaccented $-\bar{a}$ within a pāda. It seems, however, that the form vibhvām is not due to the editors, but was used by the poets themselves, as words in -v(-)an- often have the nom.sg. ending -vām̆ before vowels (e.g. maghávāmă, sahấvām̆, cf. Lanman 1878: 516).

In other accentual contexts, no nasalization is found and the final $-\bar{a}$ is shortened (these are the only two instances):

\subsubsection{0g jû́rnir hóta rọ̦ūnán ám ${ }^{5} / /$ \\ 6.18.10c gambhīráya, rșváyā yó ruroja :}

Although the evidence is not extensive, we may assume that the rule $-\bar{a}>-\bar{a} \dot{m} /{ }_{0}$ - was phonetically regular within a pāda at some stage of the oral tradition. This rule may have been operative at a pāda boundary as well, but as there are counter-examples (cf. above, $\S 2.2$ ), it seems safer to attribute nasalization at a pāda boundary to secondary extension. ${ }^{6}$

\section{$\S 3.3$. The other cases}

The last group consists of four cases of nasalized -ấ before unaccented a-:

$1.129 .9 \mathrm{~b}$ yāhí pathấm anehásā :

1.133.6bc śrusóca hí dyaúh, kṣấ ná bhīṣám adrivo :

ghrnấn ná bhīṣám adrivạ̣ /

5.6.10a evā́m agním ajuryamụ :

5.25.9a evấm agním vasūyávah :

Of course there are numerous instances without nasalization. For instance, at the beginning of a pāda we find three times evấgní-, which must be read evá (or evấ) agní- with hiatus (1.77.5a, 7.42.6a, 10.115.7a).

As Oldenberg noticed (1888: 471f.), the final vowel of bhịsấm in 1.133.6bc must be metrically short, so that bhịsấ is a preferable form (vocalis ante vocalem corripitur). In other words, the nasalized form could be introduced into the text only by the editors and only at a rather late

\footnotetext{
${ }^{5}$ For the short a's in the gen.pl. ending cf. Oldenberg 1888: 163ff. It is difficult to determine whether the first or the second a was accented.

${ }^{6}$ There is no nasalization, whatever the accentual context, if the metre shows that there is no hiatus involved. Here are some examples:

2.28.5d mấ mấtrā sāìiy, apásaḥ purá rón tọ // (i.e. purá rtóh)

5.46.1d vidvấn patháh, puraetá rjú neșati // (i.e. puraetá rjú, etc.)

$3.43 .5 \mathrm{c}$ kuvín ma ŕssim, papivấmsam sutásya :

8.8.6ab yác cid dhí vām purá ṛ́sayạ :

$2.24 .13 \mathrm{c}$ vịludvéșā, ánu vása rnám àdadíh :

2.28.9a pára rọấ sāvīr, ádha mátkrtāni :

$5.41 .15 \mathrm{~d}$ smát sūribhir, rjucuásta rjuvániḥ //

10.68.4a āprușāyán, mádhuna rósya yónim :
} 
date, when the metrical rules were not observed any more.

From the numerous exceptions and metrical problems we may conclude that nasalization

of -áa before unaccented a- is not original and only imitates the rule $-\bar{a}>-\bar{a} m /{ }_{0}$-, where nasalization is regular.

$\S 4$. In the preceding sections we have seen that the determinant for nasalization of the final $-\bar{a}$ was accentuation. Arisen in specific accentual contexts, nasalization was later introduced into other positions and became a device to prevent contraction. Chronologically we may date the rise of nasalization to the first stages of editing of the RV, when the metrical structures were still transparent to the editors. Nasalization occurs in three different positions:

1. Nasalization of unaccented pāda-final -⿳亠二厶̆, which is followed by accented é- and ó- (15 occurrences). This rule was extended analogically to other accentual contexts $(3 x)$ and to the position within a pāda (1x).

2. Nasalization of accented -ắ before unaccented $r_{0}$-. We find this phenomenon twice within a pāda (no exceptions), which probably was the original locus, and three times at a pāda boundary (two instances with no nasalization). It seems likely that the four occurrences of nasalized -ắm before unaccented a- are due to secondary extension of the rule $-\bar{a}>-\bar{a} m /{ }_{0}$-.

3. Nasalization of the pāda-final postposition $\bar{a}$ before a vowel (21x without a single exception). Here no accentual conditions are found. This rule was probably extended to the pādafinal postposition sácā, which is attested $7 \mathrm{x}$ with nasalization and twice contracted with the following vowel.

As the pāda-final postposition $\bar{a}$ is nasalized before every vowel and as there was an obvious need to prevent its contraction (cf. $\S 2.3$ ), I believe that nasalization of á is secondary. The editors could make use of phonetic nasalization of -á before ${ }_{o}^{r}$ - in order to keep a pāda boundary transparent.

We arrive at two phonetic rules which are responsible for the rise of nasalization:

$-\bar{a}>-\overline{a ̆ m} / \ldots$ : é-,ó- and

$-\bar{a}>-\bar{a} \dot{m} /{ }_{0} r$.

$\S 5$. These rules are reminiscent of the lengthening rules for the final $-a$ in the Maitrāyaṇ̄ Saṃitā (MS), the other texts of the Maitrāyaṇīya school and the Kapiṣthala Kạtha Saṃitā. ${ }^{7}$ The first rule is comparable with the Maitrāyaṇiya sandhi, according to which "a final unaccented $a$ is lengthened before an accented vowel" (Lubotsky 1983: 169f.). This sandhi applies to $-a<-e$, -as before any accented vowel and to -a before ${ }_{\circ}^{r}$ - (and also twice before íti, where a different interpretation is possible, cf. Strunk 1983: 32f.). To be sure, the Maitrāyaṇiya

\footnotetext{
${ }^{7}$ Connection of Rogvedic nasalization with lengthening in MS has already been suggested by Wackernagel (AiGr.I: 314f.: "ähnlich MS... mit Dehnung des unkontrahirten a..."), but without any reference to the essential role of accentuation in either the MS or the RV.
} 
and the Rgvedic rules are not identical, but the conditions concerning hiatus and the accentual context are strikingly similar.

Moreover, the old manuscripts of the MS use a special sign in the form of a recumbent devanāgarī six, which in combination with the usual anudātta stroke accompanies every long anudātta in hiatus. As I have argued in the above-mentioned article, this sign is identical with the sign attested in the manuscripts of the Vājasaneyi Sampitā (VS), where it marks a so-called kampa (an independent svarita before an udātta). The kampa syllable must bear two accents, viz. the svarita and the anudātta, which is indispensable for the correct understanding of the next udātta. Therefore, this special sign in both cases designates a combination of two accents on one syllable: a combination of a svarita with an anudātta in the VS, a combination of an anudātta with an udātta in the MS. This combination in the MS arose because of the anticipatory rise of the anudātta in hiatus. The realization of two accents on one syllable protracted the vowel concerned, and the only possible short vowel in hiatus, $\breve{a}$, was consequently lengthened.

It seems reasonable to assume the same origin for the Rgvedic nasalization rule. As we have seen above ( $§ 2.2$ ), nasalization must have arisen at the first stages of editing of the RV, when the editors were still aware of the metrical structure of the verse (cf. Oldenberg 1888: 427ff. on the sandhi $-\bar{a} n V->-\bar{a} m{ }^{\prime} V$-). Most likely, this editorial work took place at the time of the early Brāhmaṇas, i.e. simultaneously with texts like the MS.

What happened then with the Rgvedic pāda-final -ă in hiatus? The reciters tried to preserve a pāda boundary, but had some difficulty in pronouncing correctly the accents in this artificial hiatus, as the accent of the second vowel affected the accent of the first. If we take into consideration the phonetic features of the Vedic accents (the udātta was a rising tone, anudātta low, and svarita falling, cf. Lubotsky 1988: 23), we see that only one accentual combination, anudātta + udātta, could be misunderstood because the early anticipatory rise of the pitch on the anudātta would turn it into an udātta. In the other combinations this anticipation did not lead to confusion.

It follows that in hiatus of anudātta + udātta, the reciters had to combine two tonal movements on the first syllable, viz. the low anudātta and the beginning rise of the udātta. Realization of two tonal movements on one syllable led to protraction of this syllable and to its nasalized pronunciation. ${ }^{8}$

\footnotetext{
${ }^{8}$ The nasalized pronunciation of final -ă in hiatus is typologically parallel to a development attested in Tibetan (cf. Matisoff 1975) and in the Samoyed languages, where a- gets an initial $y$-. Phonetically, this nasal is due to relaxation of the vocal tract and lowering of the velum, which accompanies pronunciation of a vowel (especially, an unarticulated vowel [ə]) if this vowel is not preceded by a glottal stop. The increasing number of vowel contractions in Vedic of the post-Rogvedic period show that this language did not have an automatic glottal stop before an initial vowel any more. This led to the rise of phonetic nasalization of final - $\bar{a}$ in hiatus, which was phonemicized in specific environments. Note that the Vedic Anunāsika was an uvular nasal (Witzel 1983).

Another example of a similar phonetic development is the Avestan rule *aha $>$ anha and *āha $>$ ăgha.
} 
This development also explains why the particle $u$ appears in the Padapātha text as ūm íti. The Padakāra considered $u$ uncombinable (pragrhya) and put íti after every occurrence of this word in the pada text. The resulting hiatus of anudātta + udātta ( $u$ íti) led to protraction and nasalization of $u$. The only difference with the rule $-\bar{a}>-\breve{a ̆ m} / \ldots$ : é-, ó- is the lengthening of the vowel, which is noted down in the case of $\bar{u}$, but left unmarked in our rule. This discrepancy is probably due to the closed character of $u$, which is much shorter than a.

Another parallel is offered by the Vedic pluti, which is used in sentence questions, disjunctive questions and in several cases of calling to a distance. The pluti is always accompanied by lengthening of the vowel and sometimes, if the vowel stands in absolute final position, by its nasalization. An example of such nasalization is attested in the RV, cf.:

\subsection{1 cd kathấ grấmam, ná prchasi : \\ ná tvā bhír, iva vindatī3m̈ //}

"Wie kommt es, daß du nicht nach dem Dorfe fragst? Überfällt's dich nie wie Furcht?" (Geldner)

As Strunk (1983: 101ff.) has demonstrated, the Vedic pluti is primarily a rising intonational contour. We may assume that realization of this contour on one syllable resulted in protraction and nasalization, which is parallel to our rule.

Finally, we must try to answer the question: why is nasalization of - $\breve{\bar{a}}$ restricted to the position before é-, ó-? It is important to mention in this connection that sandhi of $-\overline{\bar{a}}+\mathrm{e}-/ \mathrm{o}$ - sometimes yields e- / o- with elision of the final - $\check{\bar{a}}$ instead of the usual contraction to -ai- / -au- (RPr. 175ff). Above ( $\$ 2.1)$ we have already met with two cases of elision of the pāda-final - $\breve{\bar{a}}$ before evá (7.33.3ab tatārevá = tatāra : evá, 8.9.9cd aśvinevá = aśvinā : evá). We further find 8.5.3 yáthohiṣe = yáthā ohiṣe (but cf. Oldenberg, Noten ad loc.), 10.91.4 ivétayạ = iva étayạ (10.148.3 ratholha, RPr. 175, Pp. ratha-ọ̣ha, must be analysed ratha- $\bar{u}$ ḍha; likewise 8.82.2 yáthociṣé, Pp. yáthā ociṣé must be analysed yáthā ūciṣé; the analysis of the proper names dasoni-, dasonya- = dasa-oni-(?) is uncertain). ${ }^{9}$ In the later texts, elision of -ă before e- / obecomes more frequent, and we may assume that the editors had more problems with pronouncing hiatus of $-\breve{a}+e-/ o$ - correctly than hiatus of the other vowels.

§ 6. The second Rovedic nasalization rule, viz. $-\bar{a}>-\bar{a} \dot{m} /{ }_{0}$-, is comparable to a rule attested in the prose sections of the MS, according to which final -a in forms of demonstrative pronouns is lengthened before ${ }_{\circ}$ - (Lubotsky 1983: 177, fn. 1), cf.:

I.5.4: 71ff. sấ rchatu (all mss. write sấ richatu);

I.7.2: 110,8; III.4.5: 50,11 ví syấ rodhyate;

II.2.9: 22,14 eșá ŕóddhīnām;

III.4.4: 49,8 eténā rónvo.

\footnotetext{
${ }^{9}$ Elision of - $\breve{a}$ before other vowels is not attested. Examples of elision of -ă before a-, given by the RPr., are all due to mistakes of the Pp.
} 
In mantras this lengthening does not occur, cf.:

IV.10.2: 147,10 sá rọtún (=RV 10.2.4d);

IV.10.6: 158,8 sá ró rúbhih;

IV.12.1: 178,5 sa rovatà (=RV 4.50.5a).

The grammatical conditioning of the Maitrāyaniya lengthening is most probably secondary, and it is conceivable that the original rule was restricted to accented final -á before

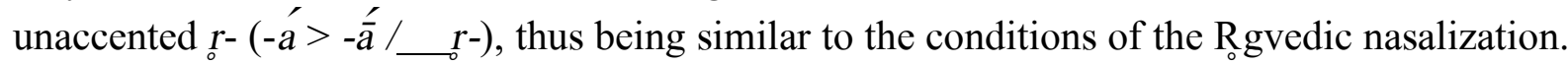

Phonetic justification for the rule must be sought in the pronunciation of $r$-. According to the RPr. (rule 742), " $r$ is in the middle of the vocalic $r$ ", i.e. there is a phonetic shwa before and after the $r\left(\left[{ }^{\partial} r^{\partial}\right]\right)$. A comparable description is also given by the other Prātisākhyas (cf. Wackernagel AiGr.I: 31 with Debrunner's Nachträge). It was apparently difficult to pronounce the rising contour of an udātta on the final -ấ in combination with a different pitch on the first shwa of the initial $r_{0}$ -

REFERENCES

Arnold, E.V. 1905: Vedic metre in its historical development. Cambridge.

Benfey, Th. 1880: Vedica und Linguistica. Strassburg - London.

Bollensen, Fr. 1868: Die Lieder des Parāçara. ZDMG 22, 569-653.

Geldner, K.F.: Der Rig-veda, aus dem Sanskrit ins Deutsche übersetzt..., 4 vols. Cambridge, Mass., 1951-1957.

Grassmann, H.: Wörterbuch zum Rig-veda. Wiesbaden, $1976^{5}$.

Lanman, C.R. 1878: A statistical account of noun-inflection in the Veda. JAOS 10, 325-600.

Lubotsky, A. 1983: On the external sandhis of the Maitrāyaṇi Saṃitā, Indo-Iranian Journal 25, 167-179.

Lubotsky, A. 1988: The System of Nominal Accentuation in Sanskrit and Proto-Indo- European, Leiden.

Matisoff, J.A. 1975: Rhinoglottophilia: the mysterious connection between nasality and glottality. Nasálfest: papers from a symposium on nasals and nasalization, ed. by Ch.A. Ferguson, L.M. Hyman, J.J. Ohala. California, 265-287.

MS: Maitrāyạ̣i Saṃhitā, herausg. von L. von Schroeder, 4 Bde. Leipzig, 1881-1886.

Oldenberg, H. Noten: Roveda: Textkritische und exegetische Noten. 2 vols. Berlin, 1909-1912.

Oldenberg, H. 1888: Die Hymnen des Rigveda. Band I: Metrische und textgeschichtliche Prolegomena. Berlin.

Oldenberg, H. 1901: Rogveda VI, 1-20. ZDMG 55, 267-330.

Pp.: Rogvedasaṃhitā-padapătha, ed. by G.R. Josyer. Mysore, 1947.

Renou, L. EVP: Études védiques et pāninéennes, 17 vols. Paris, 1955-1969.

RPr.: Rig-Veda-Prātisākhya, das älteste Lehrbuch der vedischen Phonetik, herausgegeben von M. Müller. Leipzig, 1869.

RV: Die Hymnen des Rigveda, herausg. von Th. Aufrecht. Bonn, $1877^{2}$.

Strunk, K. 1983: Typische Merkmale von Fragesätzen und die altindische 'Pluti'. Bayerische Akademie der Wissenschaften, Phil.-hist. Klasse, Sitzungsberichte, Jg. 1983, Heft 8. München.

TPr.: The Tāittirīya-prātisākhya, with its commentary the Tribhāshya- ratna: text, translation and notes by W.D. Whitney. New Haven, 1871.

Wackernagel, J. AiGr. I: Altindische Grammatik. Band I: Lautlehre. Nachträge von A.Debrunner. Göttingen. $1957^{2}$. Witzel, M. 1983: Anunāsika in Medieval Veda Tradition (Materials on Vedic Śākhās 3). Indo-Iranian Journal 25, 180. 